\title{
Does tranexamic acid reduce desmopressin-induced hyperfibrinolysis?
}

Ertuğrul Özal, MD

Erkan Kuralay, MD

Hakan Bingöl, MD

Faruk Cingöz, MD

Süleyman Ceylan, MD

Harun Tatar, MD
From the Gülhane Military Medical Academy Cardiovascular Surgery Department Etlik, Ankara, Turkey.

Received for publication Feb 6, 2001; revisions requested March 21, 2001; revisions received April 6, 2001; accepted for publication May 14, 2001

Address for reprints: Ertuğrul Özal, MD, GATA Lojmanları Pamir Apt. No:15, Etlik, Ankara, Turkey 06010 (E-mail: ozal@ tr.net).

J Thorac Cardiovasc Surg 2002;123:539-43

Copyright (c) 2002 by The American Association for Thoracic Surgery

$0022-5223 / 2002 \$ 35.00+0 \quad \mathbf{1 2 / 1 / 1 1 7 2 8 1}$

doi:10.1067/mtc.2002.117281
Objective: Desmopressin releases tissue-type plasminogen activator, which augments cardiopulmonary bypass-associated hyperfibrinolysis, causing excessive bleeding. Combined use of desmopressin with prior administration of the antifibrinolytic drug tranexamic acid may decrease fibrinolytic activity and might improve postoperative hemostasis.

Methods: This prospective randomized study was carried out with 100 patients undergoing coronary artery bypass operations between April 1999 and November 2000 in Gülhane Military Medical Academy. Patients were divided into 2 groups. Desmopressin $(0.3 \mu \mathrm{g} / \mathrm{kg})$ was administrated just after cardiopulmonary bypass and after protamine infusion in group $1(\mathrm{n}=50)$. Both desmopressin and tranexamic acid (before the skin incision at a loading dose of $10 \mathrm{mg} / \mathrm{kg}$ over 30 minutes and followed by 12 hours of $\left.1 \mathrm{mg} \cdot \mathrm{kg}^{-1} \cdot \mathrm{h}^{-1}\right)$ were administrated in group $2(\mathrm{n}=50)$.

Results: Significantly less drainage was noted in group $2(1010 \pm 49.9 \mathrm{~mL}$ vs 623 $\pm 41.3 \mathrm{~mL}, P=.0001)$. Packed red blood cells were transfused at $2.1 \pm 0.5$ units per patient in group 1 versus $0.9 \pm 0.3$ units in group $2(P=.0001)$. Fresh frozen plasma was transfused at $1.84 \pm 0.17$ units per patient in group 1 versus $0.76 \pm 0.14$ units in group $2(P=.0001)$. Only $24 \%$ of patients in group 2 required donor blood or blood products compared with $74 \%$ of those in the isolated desmopressin group (group $1, P=.00001$ ). Group 1 and group 2 findings were as follows: postoperative fibrinogen, $113 \pm 56.3 \mathrm{mg} / \mathrm{dL}$ versus $167 \pm 45.8 \mathrm{mg} / \mathrm{dL}(P=.0001)$; fibrin split product, $21.2 \pm 2.3 \mathrm{ng} / \mathrm{mL}$ versus $13.5 \pm 3.4 \mathrm{ng} / \mathrm{mL}(P=.0001)$; and postoperative hemoglobin level, $7.6 \pm 1.2 \mathrm{~g} / \mathrm{dL}$ versus $9.1 \pm 1.2 \mathrm{~g} / \mathrm{dL}(P=.0001)$.

Conclusion: Tranexamic acid administration significantly reduces desmopressin and bypass-induced hyperfibrinolysis. Combined use of tranexamic acid and desmopressin decreases both postoperative blood loss and transfusion requirement.

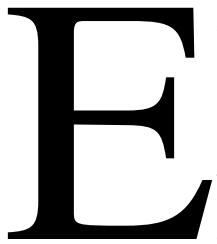

xcessive bleeding after cardiac operation is a major concern for cardiac surgeons. It has been reported in $5 \%$ to $25 \%$ of patients undergoing cardiopulmonary bypass (CPB). However, only $3 \%$ to $5 \%$ of all patients undergoing cardiac operations require reoperation for bleeding. ${ }^{1}$ This figure becomes more important in view of the increasing number of reoperations and emergency surgical procedures during which patients are still under the effect of antiplatelet or fibrinolytic agents. ${ }^{2}$ Hemostatic drugs are among the measures available to decrease bleeding and transfusion. Aprotinin, ${ }^{3}$ desmopressin, ${ }^{4,5}$ and lysine-analogue antifibrinolytic preparations, such as $\varepsilon$-aminocaproic acid ${ }^{2}$ and tranexamic acid, ${ }^{6}$ may provide salu- 
TABLE 1. Patient demographics

\begin{tabular}{|c|c|c|c|c|c|}
\hline & \multicolumn{2}{|c|}{ Group $1(n=50)$} & \multicolumn{2}{|c|}{ Group 2 ( $n=50$ ) } & \multirow[b]{2}{*}{$P$ value } \\
\hline & Mean \pm SD & $\mathbf{n}$ & Mean \pm SD & $\mathbf{n}$ & \\
\hline Female sex (n) & & 12 & & 15 & $.27^{*}$ \\
\hline Age (y) & $61 \pm 7$ & & $59 \pm 4$ & & $.32 \dagger$ \\
\hline Distal anastomosis & $2.3 \pm 0.5$ & & $2.5 \pm 0.4$ & & $.71 \dagger$ \\
\hline Crossclamp time (min) & $44 \pm 7$ & & $51 \pm 4$ & & $.12 \dagger$ \\
\hline Total perfusion time (min) & $56 \pm 6$ & & $61 \pm 5$ & & $.18 \dagger$ \\
\hline LITA & & 50 & & 50 & $1^{*}$ \\
\hline RITA & & 10 & & 9 & $.81^{*}$ \\
\hline Radial artery & & 31 & & 25 & $.19^{*}$ \\
\hline Saphenous vein & & 11 & & 15 & $.26^{*}$ \\
\hline
\end{tabular}

LITA, Left internal thoracic artery; RITA, right internal thoracic artery. ${ }^{*} \chi^{2}$ Test was used.

tStudent $t$ test was used.

tary hemostatic effects. Desmopressin acetate has been found to shorten bleeding time, thus reducing blood loss. It acts by inducing the release of von Willebrand factor from the endothelial cells. ${ }^{7}$ Desmopressin also transiently releases tissue-type plasminogen activator from endothelial cells. ${ }^{8}$ Plasminogen activator could augment a CPB-associated fibrinolytic state. ${ }^{9}$ Augmented fibrinolysis induced by release of tissue plasminogen activator might negate a salutary effect of desmopressin. If so, then prior treatment with a potent antifibrinolytic agent should unmask a desmopressin-mediated decrease in bleeding and transfusion requirement. Tranexamic acid attaches to lysine-binding sites on plasminogen and plasmin to inhibit binding to fibrinogen and fibrin. Because plasmin and plasminogen can not bind to fibrin and fibrinogen, fibrinolysis is inhibited. ${ }^{10}$

We investigated the separate and combined hemostatic effects of tranexamic acid, a potent antifibrinolytic agent, and desmopressin during cardiac surgery in an effort to determine whether the salutary effect of tranexamic acid on desmopressin induced the fibrinolytic state.

\section{Materials and Methods}

One hundred elective coronary artery bypass operations were performed between April 1999 and November 2000. Patients were divided into 2 groups, with each group including 50 patients. The purpose of the study was explained to all patients. Informed consent was also obtained from all patients. Tables of random digits were used for randomization of patients. ${ }^{11}$ Bleeding amount, reoperation, and transfusion requirement were analyzed in this prospective randomized study. Desmopressin $(0.3 \mu \mathrm{g} / \mathrm{kg}$ administered intravenously over 20 minutes) was administrated in group 1 $(\mathrm{n}=50)$ patients just after extracorporeal circulation and after completion of protamine infusion. Tranexamic acid and desmopressin were both administrated in group $2(\mathrm{n}=50)$ patients before the skin incision at a loading dose of $10 \mathrm{mg} / \mathrm{kg}$ over 30 minutes, followed by 12 hours at $1 \mathrm{mg} \cdot \mathrm{kg}^{-1} \cdot \mathrm{h}^{-1}$. Desmopressin was admin- istrated as in group 1. Informed consent was obtained from all patients in each group.

Patients were excluded from participation if they took warfarin or estrogen within 10 days, had active hematuria, had a serum creatinine concentration of $2 \mathrm{mg} / \mathrm{dL}$ or greater, had a personal or family history of abnormal bleeding, or underwent intra-aortic balloon counterpulsation. Patients receiving aspirin within 10 days of the operation or nonsteroidal anti-inflammatory medication within 5 days of the operation were also excluded from the study. Enrolled patients underwent coronary revascularization only. Patient demographics are summarized in Table 1.

CPB was established with a roller pump nonpulsatile flow after anticoagulation with bovine lung heparin $(3 \mathrm{mg} / \mathrm{kg})$, and activated clotting time was maintained for more than 480 seconds. Membrane oxygenators (Capiox-E Terumo Corp, Tokyo, Japan) were used in all cases. Heparin was reversed by administration of protamine $(3.5 \mathrm{mg} / \mathrm{kg})$ at the end of the CPB period. All distal anastomoses were performed in a single crossclamp period. The left internal thoracic artery was used in all patients. The right internal thoracic artery was used in 19 patients, and the radial artery was used in 56 patients in both groups. The saphenous vein was harvested as needed. Posterior pericardiotomy was done in all patients, as described by Mulay and coworkers. ${ }^{12}$ After routine closure of the chest, continuous suction $(10 \mathrm{~mm} \mathrm{Hg})$ was applied to drains, which were milked and stripped at 30-minute intervals to ensure tube patency. Chest tubes were removed when the drainage was less than $20 \mathrm{~mL} / \mathrm{h}$ for 4 consecutive hours.

Hemoglobin concentration, hematocrit value, platelet count, prothrombin time, activated partial thromboplastin time, fibrinogen, and fibrin split products (FSPs) were measured before the operation and an hour after the patients arrived in the intensive care unit. Homologous packed red cells were administered only when the hematocrit value fell to less than $25 \%$. Patients received fresh frozen plasma when excessive blood loss was accompanied by a prolonged ( $>1.5$ times normal values) prothrombin time. Additional protamine was administered if the activated clotting time/control time ratio was greater than 1.5. Platelet transfusion was used when the platelet count fell below $40,000 / \mathrm{mL}$. Shed blood was not autotransfused in 
TABLE 2. Bleeding amount and total transfusion requirement

\begin{tabular}{lccc}
\hline & Group 1 & Group 2 & P value \\
\hline $\begin{array}{l}\text { Total bleeding } \\
\text { amount (mL) }\end{array}$ & $1010 \pm 49.9$ & $623 \pm 41.3$ & $.0001^{*}$ \\
$\begin{array}{c}\text { Fresh frozen plasma } \\
\text { (units/patient) }\end{array}$ & $1.84 \pm 0.17$ & $0.76 \pm 0.14$ & $.0001^{*}$ \\
$\begin{array}{c}\text { Packed red blood } \\
\text { cells (units/patient) }\end{array}$ & $2.1 \pm 0.5$ & $0.9 \pm 0.3$ & $.0001^{*}$ \\
$\begin{array}{l}\text { Platelets (units/patient) } \\
\text { Patients receiving } \\
\text { transfusion (\%) }\end{array}$ & 0.02 & 0.02 & $1 \dagger$ \\
\hline
\end{tabular}

Values are given as means \pm SD.

* Student $t$ test was used.

$t \chi^{2}$ Test was used.

any of the patients during the study. Reoperation was undertaken if blood loss exceeded $500 \mathrm{~mL}$ for 2 consecutive hours without signs of decreasing despite appropriate therapy.

CPB time, total operation time, amount of total chest drainage, prevalence of reoperation for bleeding, cause of bleeding, need for donor blood transfusion or fresh frozen plasma, and thrombocyte suspension were recorded for all patients. The course of the blood hemoglobin content and FSPs during the hospitalization were analyzed in each patient.

Statistical analysis was performed with SPSS software version 7.0 (SPSS Inc, Chicago, Ill). Clinical data are expressed as mean values \pm SD. Differences were analyzed with the Student $t$ test and $\chi^{2}$ test.

\section{Results}

No differences were found between groups 1 and 2 in patient age, sex, crossclamp use, and CPB time. Also, the number of bypass grafts and the number of right internal thoracic arteries, left internal thoracic arteries, and radial arteries used per patient undergoing coronary artery bypass graft operation were not statistically different between the groups (Table 1). Significantly less total postoperative drainage was noted in group $2(1010 \pm 49.9$ vs $623 \pm 41.3 \mathrm{~mL}, P=.0001)$. Platelet transfusion was required in 2 patients in both groups. The use of banked donor blood products during the operation was statistically significant. Packed red blood cells were transfused at $2.1 \pm 0.5$ units per patient in group 1 versus $0.9 \pm 0.3$ units in group $2(P=.0001)$. Fresh frozen plasma was transfused at $1.84 \pm 0.17$ units per patient in group 1 versus $0.76 \pm 0.14$ units in group $2(P=.0001)$ Transfusion requirements were significantly lower in group 2 . Only $24 \%$ of patients in group 2 required donor blood or blood products compared with $74 \%$ of those in the isolated desmopressin (group 1) group $(P=$ .00001, Table 2).

There were no statistically significant differences between the 2 groups with regard to platelet count, prothrombin use, and partial thromboplastin time, but there were statistically significant differences with regard to postoperative fibrinogen $(113 \pm 56.3 \mathrm{mg} / \mathrm{dL}$ vs $167 \pm 45.8$
TABLE 3. Hematologic values and coagulation tests

\begin{tabular}{|c|c|c|c|}
\hline & Group 1 ( $n=50)$ & Group 2 ( $n=50)$ & $P$ value \\
\hline \multicolumn{4}{|l|}{ Hemoglobin (g/dL) } \\
\hline Preoperative & $13.2 \pm 1.3$ & $13.5 \pm 1.5$ & .288 \\
\hline Postoperative & $7.6 \pm 1.2$ & $9.1 \pm 1.2$ & .0001 \\
\hline \multicolumn{4}{|l|}{ Platelets (109/L) } \\
\hline Preoperative & $295 \pm 75.8$ & $267 \pm 89.3$ & .09 \\
\hline Postoperative & $121 \pm 23.5$ & $126 \pm 34.4$ & .398 \\
\hline \multicolumn{4}{|c|}{ Fibrinogen (mg/dL) } \\
\hline Preoperative & $356 \pm 45.3$ & $345 \pm 56.2$ & .284 \\
\hline Postoperative & $113 \pm 56.3$ & $167 \pm 45.8$ & .0001 \\
\hline \multicolumn{4}{|c|}{ Prothrombin time (s) } \\
\hline Preoperative & $13.2 \pm 0.5$ & $13.4 \pm 1.2$ & .325 \\
\hline Postoperative & $12.8 \pm 0.7$ & $13 \pm 1.1$ & .289 \\
\hline \multicolumn{4}{|c|}{ Partial thromboplastin time } \\
\hline Preoperative & $36.1 \pm 4.2$ & $35.6 \pm 3.2$ & .504 \\
\hline Postoperative & $38.2 \pm 3.8$ & $37 \pm 2.3$ & .062 \\
\hline \multicolumn{4}{|l|}{ FSP } \\
\hline Preoperative & $5.5 \pm 2.1$ & $5.7 \pm 3.2$ & .725 \\
\hline Postoperative & $21.2 \pm 2.3$ & $13.5 \pm 3.4$ & .0001 \\
\hline
\end{tabular}

Values are given as means \pm SD. The Student $t$ test was used in all parameters.

$\mathrm{mg} / \mathrm{dL}, P=.0001)$, FSPs $(21.2 \pm 2.3 \mathrm{ng} / \mathrm{mL}$ vs $13.5 \pm 3.4$ $\mathrm{ng} / \mathrm{mL}, P=.0001)$, and postoperative hemoglobin level (7.6 $\pm 1.2 \mathrm{~g} / \mathrm{dL}$ vs $9.1 \pm 1.2 \mathrm{~g} / \mathrm{dL}, P=.0001$; Table 3$)$. There were also no significant differences between the groups in postoperative hemodynamics, duration of stay in the intensive care unit, and duration of postoperative hospital stay (data not shown). One patient in each group underwent reoperation for excessive bleeding. A sternal bleeding site was identified. There were no instances of renal impairment or allergic reaction to hemostatic drugs in either group. Transient hypotension developed in 6 patients in group 1 and in 4 patients in group 2. The rate of infusion of desmopressin reduced, and hypotension gradually disappeared. Two patients (one of them in group 1) had deep venous thrombosis during the days of hospitalization. Perioperative myocardial infarction developed in 3 patients (one of them in group 1), but hemodynamic instability did not develop in these patients.

\section{Discussion}

The hemostatic defects associated with CPB are complex, and the reasons for excessive postoperative bleeding are multifactorial. However, qualitative and quantitative platelet defects $^{1,13-15}$ have been shown to be an important factor, especially with CBP time. ${ }^{13}$ Contact with a synthetic surface results in $\alpha$-granule release, with subsequent reduced aggregation and adhesiveness of the platelet. Although these defects are short lived (1-2 hours), they contribute to excessive blood loss and the increased use of homologous blood and blood-component therapy. ${ }^{13}$ 
TABLE 4. Comparison of major clinical evaluations of desmopressin in reducing post-CPB blood loss and transfusion requirement

\section{Table available in print only}

Desmopressin acetate is one form of pharmacologic therapy that may be efficacious in decreasing platelet dysfunction. Desmopressin enhances platelet effectiveness by increasing plasma levels of high multimetric von Willebrand factor, ${ }^{16}$ factor VIIIc, factor VIIIag, ${ }^{16}$ and other undefined mechanisms. ${ }^{17}$ Recently, many reports about use of desmopressin in cardiac surgery have been published (Table 4). ${ }^{4,18-26}$ In some of these studies, desmopressin has a salutary effect on postoperative blood loss and transfusion requirements, ${ }^{4,18}$ but mostly, transfusion requirements were not different from those of placebo groups. ${ }^{19-25}$ LoCicero $^{26}$ has pointed out that desmopressin increased both transfusion requirement and blood loss. Both postoperative blood loss $(1010 \pm 49.9 \mathrm{~mL}$ vs $623 \pm 41.3 \mathrm{~mL}, P=.0001)$ and transfusion requirement ( $74 \%$ vs $24 \%, P=.00001)$ were significantly increased in our group 1 patients. Melissari and coworkers ${ }^{8}$ and Küçük and colleagues ${ }^{9}$ revealed that desmopressin transiently releases tissue-type plasminogen activator from endothelial cells. These plasminogen activators could augment the CPB-associated fibrinolytic state. ${ }^{9,13}$ We routinely measured FSPs and noticed that FSPs statistically significantly increased in group 1 when compared with levels in group $2(21.2 \pm 2.3 \mathrm{ng} / \mathrm{mL}$ vs $13.5 \pm 3.4 \mathrm{ng} / \mathrm{mL}, P$
$=.0001)$. Postoperative fibrinogen also decreased in our study as a result of increased fibrinolytic activity in group 1 $(113 \pm 56.3 \mathrm{mg} / \mathrm{dL}$ vs $167 \pm 45.8 \mathrm{mg} / \mathrm{dL}, P=.0001)$. If the fibrinolytic activity is abolished by a lysine-analogue antifibrinolytic preparation, such as tranexamic acid, desmopressin exerts salutary effect on platelets. Of group 2 patients ( $\mathrm{n}=50$ patients), those receiving both desmopressin and tranexamic acid had statistically significant results when total blood loss $(P=.0001)$ and total transfusion requirement $(P=.0001)$ were considered. Our reoperation rate was also extremely low. We believe that it fully depended on posterior pericardiotomy, ${ }^{12}$ which significantly reduces the incidence of pericardial tamponade.

Both fibrinolysis and partial platelet activation during CPB with subsequent platelet dysfunction may alter hemostasis after CPB. ${ }^{9,13}$ Because plasmin induces platelet activation, a potential role for lysine-analogue antifibrinolytic medications is to block plasmin receptors on platelets inhibiting local fibrinolysis-induced partial platelet activation. ${ }^{27}$ Administration of tranexamic acid before CPB is associated with preserved platelet adenosine diphosphate and decreased bleeding after CPB. ${ }^{28}$ We thought that tranexamic acid not only masks fibrinolytic activity of desmopressin but also exerts hemostatic 
effects by means of platelet preserving. The data of Horrow and coworkers ${ }^{29}$ suggest that desmopressin-induced release of tissue plasminogen activators plays no role in desmopressin's lack of hemostatic effect during cardiac surgery. Horrow and coworkers also demonstrate that tranexamic acid decreases the incidence of FSPs, decreases blood loss after surgery, and decreases the likelihood of homologous blood transfusion. We did not have an isolated tranexamic acid group, and therefore we could not compare our results with those for isolated tranexamic acid administration. The study by Horrow and coworkers not only included coronary artery surgery but also valve and congenital defect operations.

Stroke, myocardial infarction, and deep vein thrombosis were also reported after use of hemostatic drugs. Stroke did not develop in our study, but deep vein thrombosis in leg veins developed in 2 patients. Deep vein thrombosis was treated with classical therapy in the postoperative period. Perioperative myocardial infarction developed in 3 patients (one of them in group 1). Horrow and coworkers ${ }^{29}$ reported their stroke incidence as $7.89 \%$ (3/38) in the isolated desmopressin group and $2.5 \%(1 / 40)$ in patients receiving both drugs.

Desmopressin significantly increases postoperative blood loss and transfusion requirement after coronary artery bypass surgery by releasing tissue-type plasminogen from endothelial cells. Desmopressin and CPB-associated hyperfibrinolytic state can be prevented by using tranexamic acid. Tranexamic acid and desmopressin significantly reduces postoperative blood loss and transfusion requirement.

\section{References}

1. Bick RL. Hemostasis defects associated with cardiac surgery prosthetic devices and extracorporeal circuits. Semin Thromb Hemost. 1989; 15:173-7.

2. Arom KV, Emery RW. Decreased postoperative drainage with addition of $\varepsilon$-aminocaproic acid before cardiopulmonary bypass. Ann Thorac Surg. 1994;57:1108-12.

3. Çicek S, Demirkılıç U, Özal E, Kuralay E, Bingöl H, Tatar H, et al. Postoperative use of aprotinin in cardiac operations: an alternative to its prophylactic use. J Thorac Cardiovasc Surg. 1996;112:1462-7.

4. Salzman EW, Weinstein MJ, Weintraub RM, Ware JA, Thurer RL, Robertson L, et al. Treatment with desmopressin acetate to reduce blood loss after cardiac surgery. N Engl J Med. 1986;314:1402-6.

5. Mongan PD, Hosking MP. The role of desmopressin acetate in patients undergoing coronary artery bypass surgery. A controlled clinical trial with thromboelastographic risk stratification. Anesthesiology. 1992;77:38-46.

6. Horrow JC, Hlavacek J, Strong MD, Collier W, Brodsky I, Goldman SM, et al. Prophylactic tranexamic acid decreases bleeding after cardiac operations. J Thorac Cardiovasc Surg. 1990;99:70-4.

7. Ruggeri ZM, Mannucci PM, Lombardi R. Multimeric composition of factor VIII/von Willebrand factor following administration of DDAVP: Implication for pathophysiology and therapy of von Willebrand's disease subtypes. Blood. 1982;59:1272-8.

8. Melissari E, Scully MF, Paes T, Ellis V, Kakkar VV. The influnce of DDAVP infusion on the coagulation and fibrinolytic response to surgery. Thromb Haemost. 1986;55:54-7.

9. Küçük O, Kwaan HC, Frederickson J, Wade L, Green D. Increased fibrinolysis in patient undergoing cardiopulmonary bypass operation. Am J Hematol. 1986;23:223-39.

10. Ouimet H, Loscalzo J. Fibrinolysis. In: Loscalzo J, Schafer AI, editors. Thrombosis and hemorrhage. Boston: Blackwell Scientific; 1994. p. 127.

11. Tull D, Albawn GS. Survey research: a decisional approach. New York: Intext Press Inc; 1973. p. 225.

12. Mulay A, Kirk AJB, Angelini GD, Wishheart JD, Hutter JA. Posterior pericardiotomy reduces the incidence of supraventricular arrhythmias following coronary artery bypass surgery. Eur J Cardiothorac Surg. 1995;9:150-2.

13. Harker LA, Malpass TW, Branson HE, Hessel EA II, Slichter SJ. Mechanism of abnormal bleeding in patients undergoing cardiopulmonary bypass: acquired transient platelet dysfunction associated with selective alpha-granule release. Blood. 1980;56:824-34.

14. Czer LCS. Mediastinal bleeding after cardiac surgery: etiologies, diagnostic considerations, and blood conservation methods. $J$ Cardiothorac Anesth. 1989;3:760-75.

15. Uehlinger J, Aledort LM. Blood product usage in cardiac surgery. $J$ Cardiothorac Anesth. 1989;3:776-84.

16. Kohler M, Hellstern P, Miyashita C, von Blohn G, Wenzel E. Comparative study of intranasal, subcutaneous and intravenous administration of desamino-arginine vasoprassine (DDAVP). Thromb Heamost. 1986;55:108-11.

17. Cattaneo M, Moia M, Valle PD, Castellana P, Mannucci PM. DDAVP shortens the prolonged bleeding times of patients with severe von Willebrand disease treated with cryoprecipitate: evidence for a mechanism of action independent of released von Willebrand factor. Blood. 1989;74:1972-5.

18. Czer LSC, Bateman TM, Gray RJ, Raymond M, Stewart ME, Lee S, et al. Treatment of severe platelet dysfunction and hemorrhage after cardiopulmonary bypass: reduction in blood product usage with desmopressin. J Am Coll Cardiol. 1987;9:1139-47.

19. Rocha E, Liorens R, Paramo JA, Areas R, Cuesta B, Trenor AM. Does desmopressin acetate reduce blood loss after surgery in patients on cardiopulmonary bypass? Circulation. 1988;77:1319-23.

20. Hackmann T, Gascoyne RD, Naiman SC, Growe GH, Burchill LD, Jamieson WRE, et al. A trial of desmopressin to reduce blood loss in uncomplicated cardiac surgery. N Engl J Med. 1989;321:1437-43.

21. Brown MR, Swygert TH, Whitten CW, Hebeler R. Desmopressin acetate following cardiopulmonary bypass: evaluation of coagulation parameters. J Cardiothorac Anesth. 1989;3:726-9.

22. Hedderich GS, Petsikas DJ, Cooper BA, Leznoff M, Guerraty AJ, Poirrer NL, et al. Desmopressin acetate in uncomplicated coronary bypass surgery. A prospective randomized clinical trial. Can J Surg. 1990;33:33-6.

23. Andersson TLG, Solem JO, Tengborn L, Vinge E. Effects of desmopressin acetate on platelet aggregation, von Willebrand factor and blood loss after cardiac surgery with extracorporeal circulation. Circulation. 1990;81:872-8.

24. Frankville DD, Harper GB, Lake CL, Johns RA. Hemodynamic consequences of desmopressin administration after cardiopulmonary bypass. Anesthesiology. 1991;74:988-96.

25. Lasenby WD, Russo I, Zadeh BJ, Zelano JA, Ko W, Jynch CC, et al. Treatment with desmopressin acetate in routine coronary artery bypass surgery to improve postoperative hemostasis. Circulation. 1990;82(suppl IV):413-9.

26. LoCicero J III. Any value for desmopressin (DDAVP) in cardiopulmonary bypass operation [letter]. J Thorac Cardiovasc Surg. 1990; 99:945.

27. Parise P, Hauert J, Grimaudo V, Bachmann F. Platelet activation induced by plasmin and plasminogen activators in vitro [abstract]. Fibrinolysis. 1990;4(suppl 3):156.

28. Soslau G, Horrow J, Brodsky I. The effect of tranexamic acid on platelet ADP during extracorporeal circulation. Am J Hematol. 1991; 38:113-9.

29. Horrow JC, Van Riper DF, Strong MD, Brodsky I, Parmet JL. Hemostatic effects of tranexamic acide and desmopressin during cardiac surgery. Circulation. 1991;84:2063-70. 